\title{
Article \\ Educating the Roma: The Struggle for Cultural Autonomy in a Seminomadic Group in Norway
}

\author{
Ada I. Engebrigtsen \\ Norwegian Social Research, Oslo and Akershus University College of Applied Sciences, 0130 Oslo, Norway; \\ E-Mail: ada.i.engebrigtsen@nova.hioa.no
}

Submitted: 31 March 2015 | In Revised Form: 25 August 2015 | Accepted: 8 September 2015 |

Published: 29 September 2015

\begin{abstract}
This paper will discuss the rationale of a group of Norwegian Roma who have resisted the government's attempts to educate them since the early 1960s. Behind the scenes these Roma claim that a school education is irrelevant for their children yet, when faced with school authorities, they comply. The authorities have used different approaches to promote education for Rom children however, their success is questionable. So what is at stake here? What is wrong with education from the Roma's point of view and how do the authorities respond? This article opens with a presentation of the history and background of the Norwegian Roma. It then presents the Norwegian system of public primary and lower secondary education and their attempts to accommodate Rom children. It critically examines the concept of education and the unquestioned and self-evident understanding of schooling as a liberating force per se. It further makes use of Bourdieu's analysis of symbolic capital and habitus and discusses the Roma's resistance to education and why symbolic capital developed through public school education is not converted to the Rom field.
\end{abstract}

\section{Keywords}

education; habitus; Norway; resistance; Roma; symbolic capital

\section{Issue}

This article is part of the special issue "Talking about Roma: Implications for Social Inclusion", edited by Dr. Eben Friedman (Independent Consultant and Senior Non-resident Research Associate, European Centre for Minority Issues, Germany).

(C) 2015 by the author; licensee Cogitatio (Lisbon, Portugal). This article is licensed under a Creative Commons Attribution 4.0 International License (CC BY).

\section{Introduction}

In school reports on the education of Gypsy ${ }^{1}$ children during the 1960s in Norway, teachers enthusiastically write comments like: "Gabriela wants to be a hairdresser and Radu wants to become a firefighter" and comment that education will help them achieve their goals ${ }^{2}$. Yet forty years and several educational projects later very few children have completed primary school

\footnotetext{
1 I use the term Gypsies (sigøyner in Norwegian) when I refer to reports and studies from before around 2009 when that was the official term, and Rom when I refer to the current situation. Norwegian Roma do, however, generally use the term sigøyner when speaking Norwegian and Rom when speaking Romanés.

${ }^{2}$ Unpublished report
}

and, to this day, only two have successfully completed secondary school. What happened and why?

This paper will discuss the rationale of a group of Norwegian Roma who have resisted the government's diverse attempts to educate them since the early 1960s. Behind the scenes these Roma claim that a school education is irrelevant for their children yet, when faced with school authorities, they comply. The authorities have used the carrot and stick approach to promote education for Rom children yet their success, thus far, is questionable. So what is at stake here? What is wrong with education from the Roma's point of view and how do the authorities respond?

One of the experiences from all educational efforts towards the Norwegian Roma since the 1960s is that they have been based on superficial understandings of 
the Rom way of life and of the concept of culture (Hjemdal, 1982). A wide-spread understanding of culture, at least in Norwegian public rhetoric about minorities, is that it, at worst, is an expression of a collective will that hinders individual agency and, at best, culture is limited to expressions such as: music, dress, art and language. Culture, in terms of behaviour, is not regarded as part of the personal and emotional characteristic of an individual, but a more superficial trait open to change, and is, in some contexts, considered a mistake or an expression of "false consciousness". Thus, culture should be something one may express in one's private life. These somewhat ambiguous notions are in line with the widespread idea that as soon as an individual from a minority group is taught "our" culture he/she will prefer that, as it is what is best (Wells, 2015). The Rom lifestyle is generally regarded as something of the past; that their culture will pass when they learn new ways. Furthermore, the opinion amongst school authorities is that their reluctance towards child education, wage labour and authority control is a mixtures of deviance, ignorance and naiveté.

The Roma were once believed to be an integrated part of society but, as society has changed, they have become a marginalised group in need of shelter and security and longing for state intervention. This theory runs through most evaluations, reports and action plans that the Norwegian government have developed through shifting political regimes (Hanish, 1976). Rom "culture" is generally seen as static, yet changeable, and a total "make-over" is deemed necessary for the Roma to adapt to modern society (Engebrigtsen, 2010).

As a result of these notions and expectations, projects and programs to incorporate, assimilate or integrate the Rom population in Norway have been contradictory. This is in line with general contradictions in policies towards minorities and points to the weak understanding of the personal, relational and emotional aspects of culture. To analyse the personal and social aspects of culture as driving forces of resistance, I will employ Bourdieu's concept of habitus (1986); that family history, environment, past collective and personal experiences and way of life is incorporated into the person. The notion of habitus is crucial to Bourdieu's theory of practice. Bourdieu explained practice as the result of the interplay between habitus (in terms of capital) and a social field that structures it and, in turn, is structured by it. Habitus is thus the social structure structuring and being structured by the subjective agent. Habitus is the social aspect of the subject and brings together past and present, the objective and the subjective, structure and agency (Maton, 2008). But, Bourdieu notes:

The Habitus is the spontaneity without consciousness or will, opposed as much to mechanical necessity of things without history in mechanistic theories as it is to the reflexive freedom of subjects "without inertia" in rational theories. (Maton, 2008, p. 56)

In line with Bourdieu here, I will argue that the Rom economic and social strategies are not to be seen as strategies in any intentional way, but as "culture": the "modus operandi" of the Rom person and group.

As a basis for my discussion, I will present some general ideological traits of the history of primary education in Norway and the historical background of the Norwegian Rom group. I will then analyse the Rom social field with Pierre Bourdieu's concepts of habitus and symbolic capital and discuss the value of formal education for social mobility and capital conversion in the Rom field. My main question being: Why do the Norwegian Roma avoid education?

The background for raising these questions is the increasing effort by Norwegian and international institutions to integrate the Roma into mainstream society and their reluctance to do so on the authorities' terms. Since the Norwegian Rom population was given the status of national minority in 1999, there has been a great pressure on the government to control, include and foremost to educate them (Vermeersch, 2012). The discussion is based on the Norwegian case, but is relevant for the understanding of the relationship between the Rom population and public education far beyond this case ${ }^{3}$. As Norway is a strongly developed welfare state and the Rom population is very small, the results of the continuing and unsuccessful efforts to educate the Roma should be of interest to minority educators in general.

My personal and professional interest in this relationship stems from my work with Roma in Norway and Romania, since 1980 to present day, through different contexts. From 1978 to 1985 I was employed as head of the kindergarten for Rom children that formed part of the program: Rehabilitation of the Norwegian Gypsies. I later lived with a Rom group in Transylvania and wrote my PhD on Roma and non-Roma relations in that area (Engebrigtsen, 2007). The data from my work and research among Roma in Norway and in Romania is the empirical basis for this paper; together with official reports from 1960 to present day and three master thesis' on education of Rom children by Anette Fuglevik (2014), Kristine Bjørndal (2014) and MarenJohanne Nordby (2013). These have been invaluable for my work with this article.

\section{The Norwegian Roma}

The ancestors of the Norwegian Roma started to travel and settle temporary in Norway in the late 1800s. They belong to the vlach Romanes speaking Rom population,

\footnotetext{
${ }^{3}$ No reports or academic work concerning Roma in Norway is published in English.
} 
which shows that they left Romania after the abolishment of slavery and feudalism around 1860 (Achim, 2004). Around 1930 they left Norway for Central Europe, probably to evade the assimilatory regimes directed towards Norwegian Travellers (tater). When they tried to re-enter in 1934, seeking shelter from the rising racism in Germany and Belgium, the Norwegian authorities rejected them and sent them back to Central Europe, despite their Norwegian passports and birth certificates. In 1927, Norway had passed a law that prohibited Gypsies entering the country and rejected the legality of Norwegian passports for Gypsies. Research has shown (Rosvoll, 2015) that most of this Norwegian group ended up in concentration camps and died there. During the 1950s, a small group of approximately 100 descendants and survivors arrived and applied for Norwegian citizenship, yet were only granted this several lawsuits and many years later (Hanisch, 1976). Between 1960 and 2015, the government has launched several programmes to integrate the Roma through education, settlement and wage labour.

The history of the Norwegian Roma in Norway is important because it illustrates the last phase of the exclusion and persecution of this group in Norway (Lidén \& Engebrigtsen, 2010). The Norwegian Roma that migrated from the Romanian/Hungarian regions ${ }^{4}$ had survived centuries of exclusion, persecution and discrimination as slaves and serfs in that country. This history forms the backdrop of the Rom population and their relationship with governments and majority populations.

Today the Rom population consists of around 700 people, most of them seminomadic. They live in the capital in flats and houses, generally in extended family arrangements ideally composed of a couple, their sons, daughters-in-law and children. Most families travel spring through autumn for business, for religious meetings and for social gatherings with kin from all over Europe. They make up a group held together by marriage and kinship, with cultural and political autonomy and equality as binding values and with internal competition for respect and influence. Norwegian Roma are endogamous, they practice arranged marriages and hierarchies based on age and gender. They practice the Rom judicial system based on negotiation and consensus, and the Rom cosmology based on purity and separation of gender and ethnicity (Engebrigtsen, 2007; Engebrigtsen \& Lidén, 2010; Frazer, 1995; Lidén \& Engebrigtsen, 2010; Stewart, 1997). They are Pentecostals; members of the European Rom Pentecostal church. Today there is an increase in nuclear families or single parent families. Drug abuse, criminal activity and poverty characterise some families. The Norwegian Roma are, nonetheless, tightly connected through kin-

${ }^{4}$ The Vlach Roma that lived in Romania for around 500 years as slaves and serfs. ship, marriage, business and religion. Some families rely heavily on social security benefits, whilst others rely on relatively shady business ventures such as: trading in property, asphalt laying (with Irish Tinkers) and as car dealers. Women are generally responsible for contact with social services and welfare officers. The majority are connected to Roma all over Europe.

Before discussing the Norwegian Roma's responses to formal education I will present aspects of the Norwegian School system and the education programmes developed for Roma from 1960 to the present day.

\section{Basic Principles for Primary and Lower Secondary School in Norway}

\subsection{One School for All}

In 1920 seven years of primary school became mandatory in Norway. Public schools then suppressed the earlier private schools and so the unitary schools system, which is still the basic school system in Norway ${ }^{5}$, was established. This early public unitary school was a school "for the people and of the people" as teachers were no longer recruited from the clergy, as had been done so previously, but from gifted youth that were educated at teacher training institutions (Bergesen, 2006).

During the 1930s, inspired by Europe and the US, new ideas on education and pedagogies were formulated. These ideas argued that pupils should be active participants in education and primarily learn through their own activity, not by teachers lecturing from their desks. Another idea was that pupils should work together and support each other. This "working school", as it was called, introduced teamwork as central educational model. These ideas were made official educational policy in 1939 in the Normalplanen for folkeskolen av 1939 that proclaimed: The plan is focused on training the pupils in independent work and teaching them to find the material they need by themselves (in Bergesen 2006, p. 22). This was established under a Labour government. Bergesen (2006) writes that these ideas were revolutionary at that time, stating that: "The objective of the education is not to assist pupils with unequal abilities and interests to become equally competent in their school work, but to give the pupils an education that as much as possible is fitted to their abilities and interests" (Bergesen, 2006, p. 23). He further states that this is a transition from one school regime to another: from a school where the pupil should adapt to a set curriculum, to a school based on developing the individual ability of each pupil. This and later plans were to be implemented in all schools in the country. These polices were characterised by ambigu-

\footnotetext{
${ }^{5}$ In 1965-66 99.6\% of the population attended public schools. In 2014 the percentage in public schools is $97 \%$.
} 
ous and, sometimes, contradictory goals. On the one hand, they desired to develop the individual pupil based on their abilities yet, on the other hand, they desired to use education as a means of creating the future equal society and "the future man" (Bergesen, 2006, p. 23).

The political and pedagogical currents of the 1960s-70s, with its emphasis on knowledge as relative and its quest against competition and measurements, fitted well with the social democratic school model with its intention of education for all irrespective of background. Difference in starting position should through "adapted education" (tilpasset opplæring) lead to outcome equality.

From the 1990s, the tide changed once more and the so-called "knowledge school" (kunnskapsskolen) took form as one of several expressions of the new liberalism. Research had shown that the parents' educational and class background was important if not decisive for their children's school results and future social positions in general. The new emphasis was on developing the curriculum towards a stronger focus on knowledge, individual achievement and academic ambition. The objective was, however, much the same as those that had guided pedagogical objectives since the 30s: "to make the country's population into one people in thought, words and deeds" (Hærnes in Bergesen, 2006, p. 32) ${ }^{6}$. During the 1990 s elementary schools expanded at both ends - the starting age was changed from seven to six and schools ran up until the 9th grade (previously 7th grade). Ten years of basic education was now mandatory for all.

Egalitarian ideals have dominated Norwegian schools since elementary school became mandatory in 1920, together with a tension between individualist and collectivist objectives, as expressed by the tension between "the knowledge school" and "adapted education" (Bergesen, 2006). Yet, most importantly, here as elsewhere, primary school and education in general is one of the core institutions for nation building and in national reproduction (Takle, 2010).

Increasing ethnic diversity, due to migration since the 1980s, is, however, challenging the strong emphasis on equality and on education as a vehicle for shaping a diverse population of class, gender and ethnicity into one people with the same ethos and direction. To an increasing number of pupils Norwegian schools represent a new and often strange culture, and the chance that the school culture will triumph over the family's is dependent on several factors. The quest to incorporate these new children with diverse ethos and directions into a Norwegian unified "we", rests on the school's ability to adapt to their conditions and on the families' interest in education and inclusion (Skarpenes, 2007).

${ }^{6}$ Author's translation.

\section{History of Rom Education in Norway}

\subsection{Political Awareness of Gypsy Problems in Norway 1960-1970}

The history of formal education for Roma in Norway starts around 1962 when The Norwegian Gypsy Committee was established, consisting of representatives from the Ministry of Social affairs, the Social Department of the Municipality of Oslo, Oslo Police Headquarters and the Catholic congregation in Oslo ${ }^{7}$. With this committee the Roma were, for the first time, acknowledged as a different group than Travellers (Hanisch, 1976). The Rom population consisted of approximately 100 people; they were living in caravans in a camp in the city centre. The first official plan was to treat the Roma like the Norwegian Travellers; families should be sent to the "Travellers camp" (Svanviken) and learn Norwegian work ethic, language and values. This, however, turned out to be too costly a plan (Hanisch, 1976). After pressure from, and with the cooperation of the Committee, the Municipality then established special school provisions for Rom children (St.meld.nr. 37 (1972-73) Om tiltak for de norske sigøynere 1973). In 1973, The White Paper (1972-73) stated this with regards to education for Gypsies:

To the degree that the Gypsies have stayed in Oslo, the school has been functioning. Some efforts were made simultaneously to settle some Gypsy families, without achieving permanent settlement.

and

The effort of establishing the Gypsies as Norwegian citizens turned out to be more complicated than anticipated. Partly because the Gypsies' particular way of life did not make general social measures very appropriate, and partly because the public's attitudes towards Gypsies has created problems ${ }^{8}$. (1973, p. 3)

There was no evaluation of this early education for the Roma.

In 1969 the Gypsy Committee decided to establish a fast-working committee, the Nordland Committee, ${ }^{9}$ to evaluate the work done and suggest new measures. A prominent ethnologist and university lecturer, who was a member of the larger Gypsy Committee, was appointed as leader. Other members were representatives of the Ministry of Social Affairs and the Municipality. Their mandate was to cooperate closely with the

\footnotetext{
${ }^{7}$ The Roma were Roman Catholics at that time.

${ }^{8}$ All citations from Norwegian reports etc. are translated by the author.

${ }^{9}$ Nordland utvalget.
} 
Rom leaders. That same year the Committee received a letter from two prominent family heads ${ }^{10}$ asking for cooperation with the authorities to solve some of the Gypsies' pressing problems.

The Committee concluded that the Gypsies had not managed to adapt to new economic and structural circumstances, but were left behind the general prosperity development. They therefore needed substantial reorientation based on their cultural traditions. Housing, education for children and adults, occupations and social welfare were planned. Regarding occupation, the White Paper (St.meld.nr. 37 (1972-73) Om tiltak for de norske sigøynere 1973) noted:

Passing from a roaming life to, for instance, a steady position in a Norwegian factory is too large to be realistic for Gypsies. It will therefore be necessary to plan for an occupation that is closer to what the Gypsies are used to. $(1973$, p. 6)

On education for children, the White Paper states that it should concentrate on reading, writing and arithmetic, but also social studies:

The Gypsy children will, because of their background, experience a large cultural distance to Norwegian teaching. The Committee therefore argues that teaching should be based on their special conditions. If possible, the children should temporarily be taught in their own language, Romanes. (1973, p. 5)

The White Paper then argues that teaching should take place in a separate school for Rom children and that the demands should not be too high for them, as this would be their first schooling experience. This is in line with the general new orientation in educational and minority politics in Norway, as in Europe in the 1970s: away from assimilatory programs, towards integration. Integration was understood as a tool to include people based on their own conditions and to lead them (through education) towards equal opportunities. In school, this meant adapted teaching; that children and youth should receive education based on their abilities and conditions. This pedagogical model was part of a general political development in Europe and the US inspired by the Civil Rights Movement in the US and ethnic revival movements there and in the Third World. These movements established ethnicity and minority as new categories, with rights to self-determination and participation, such as inclusion of their history and culture in school curriculum (Engen, 2010).

10 One of them presented himself as The King of the Gypsies. The letter was written by supportive Norwegian social officer and supporters in cooperation with the Rom.

\section{2. $1973-1992^{11}$ : Making Up for Past Injustice}

In 1973, the Municipality of Oslo and the state started the first regular primary school for all Roma children in Norway ${ }^{12}$. The political and pedagogical model of this project was, in many ways, modern in the sense that it represented a break away from earlier assimilation approaches and towards a model where the children and group's language and cultural world should play a decisive role. Norway had very recently started to close down the forced assimilation programs towards Travellers and the Sami, and this experience formed their approach towards the Roma. The Committee saw education as only one of several measures that should make the Roma prepared for modern society, but on their own terms. As a result, a comprehensive program called "Rehabilitation of the Norwegian Gypsies"13 was developed. To coordinate the program "the Office for Gypsy Issues" was established by the Municipality of Oslo in 1973. The programme included settlement projects where extended families were offered fully equipped "barracks" together. The Municipality also planned vocational training in different crafts $^{14}$. As Norwegian citizens, all Roma had the right to basic social welfare provisions and, as no Rom had permanent employment, every individual over 18 soon became social welfare clients (Persson, 2014). The Municipality developed a primary school system based on the new pedagogic of adapted teaching with the right for minorities to keep and develop language, religion and cultural traits. Education should be strengthened by mothertongue or bilingual teaching. Family heads, men and women, were invited to co-operate in the development of all of these processes to better their situation.

The Committee faced some dilemmas (Fuglevik, 2014) regarding whether Rom children should attend regular Norwegian classes, whether one should establish a "Gypsy school", or one should have separate classes for Rom children in mainstream schools. The Committee's basic goal was to protect Rom language and culture, in accordance with the Rom representatives, and at the same time secure the children a proper education that could help them live independently in Norway. Their seminomadic lifestyle was not seen as an aspect of their culture; it was seen as an obstacle to education. Fuglevik (2014) notes that segregated education was contested at this time; all children should

11 The following presentation of Gypsy education from 19731992 is based on an historical analysis in a master thesis by A. Fuglevik in 2014.

${ }^{12}$ All Roma were then living in Oslo.

${ }^{13}$ The program was implemented by the Municipality of Oslo, with economic support from the Ministry of Social Affairs and guided by a steering committee with representatives of the Rom.

${ }^{14}$ This was however never implemented. 
attend the same classes, but be taught according to their abilities and conditions. The solution was to establish Rom classes in Norwegian schools.

The following years Rom classes were established first in barracks near the new Rom camp close to the Oslo University and then, from approximately 1978 as Rom families were settled, in five schools in different parts of Oslo. The authorities appointed seven educated non-Rom teachers and three Roma as "mothertongue instructors". One of these non-Rom teachers describes the mother-tongue teachers as "assistants", as they had no formal education at all and could barely read and write themselves (Fuglevik, 2004). In 1978 three Norwegian teachers and the mother tongueinstructors, developed the first spelling book in Romanes and Norwegian for use in primary school (Hjemdal, 1982). In 1980 three more public schools had Rom classes. In three classes teaching was primarily in Romanes as the children only knew very little Norwegian. Whereas in classes with children that knew enough Norwegian, teaching was in that language. During this period many children attended school but, there was also a high number of truants and drop outs (Fuglevik, 2014). There were also problems with transport to and from school, as most children lived too far away to walk. In order to cut costs and to improve efficiency the number of school were reduced to five. A working group was appointed by the Ministry of Social affairs in 1996 in order to evaluate the costs. The working group commented on the very high absence among Rom pupils, but argued that even some school attendance throughout the years would tie the Roma closer to Norwegian society. They recommended that the Rom classes should carry on, but that teachers should be more preoccupied with the compulsory aspect of education and that all work directed towards Roma should have a "normalizing strategy" (Fuglevik, 2014). Then in 1990 Rom education for children and adults was centralised in one school. The justification for this change was that the children should eventually be integrated into Norwegian classes. There were some disagreements about the educational benefits of this plan where children of different ages were in the same class, but in different groups according to their abilities. However, the authorities argued that there was no longer a need to segregate the Roma in education (Fuglevik, 2014).

\subsection{2-2015: Liberalism and New Educational Paradigms}

In 1992 this centralised education was closed, in spite of protests by "the Office for Gypsy Issues" (Sigøynerkontoret), and the children were transferred to ordinary classes. In order for the Roma to respect that education is mandatory, teachers had to report absences to the Child Protection Services (Fuglevik, 2014). The following years different models were adopted; transport to and from school was offered during certain periods, home-schooling was arranged for some families whilst they were travelling, and some youngsters were offered education in the adult classes for Roma (From, 1985).

A general experience from this period was that school attendance was accidental. In some families none of the children attended school and for the children that did, most were away travelling with their families for large parts of the year (Engebrigtsen, 2010; Fuglevik, 2014). Another general trait is that educational models were changing according to the teachers' experience and knowledge, and the authorities' regulations. A woman that attended Rom classes during that period tells that they were given freedom of choice as to which subjects they would like to study, that she enjoyed school, but that she and her siblings were away from school for such long periods that they neither learned to read nor write. She also tells about the conflict within her family on the subject of school, as her father wanted the family to go on business travels when the children had classes to attend (Fuglevik, 2014). The children that frequently attended school seemed to belong to families that were slightly marginal in the Rom community with weak occupational traditions and were more or less dependent on social security benefits (Lidén, 1990).

These changes in the education of Rom children are expressions of general policy shifts regarding immigrants, minorities and integration, where individual rights were gradually given priority over collective rights. Mother-tongue education, which was never really established in primary education, was now terminated in most schools. The idea of every individual pursuing their own goals and aspirations, independent of group-belonging, was dominant and all special measures towards Roma and minorities in general were abolished (Lidén \& Engebrigtsen, 2010). Culture and ethnicity was now regarded as a private quality and not a matter for public education. Another motive for abolishing Rom education, and for closing the whole program "Rehabilitation of Norwegian Gypsies" in 1992, was a major swindle of 30 million EUR from the Central Bank, committed by the family of the "Gypsy King" who had sent the historic letter to Norwegian authorities back in 1969. In the following years there was no special educational policy for Rom children. Nonetheless, different educational models and projects were tried out for some families based on their ethnic or cultural background, with varying results ${ }^{15}$.

\section{From Poor Outcasts to National Minority}

In 1999 The Norwegian Roma were granted the status

${ }^{15}$ See Lars Gjerde (1996). 
of National Minority protected by the Council of Europe Framework Convention on the Protection of National Minorities (1995). This convention that protects minorities against discrimination and states their right to maintain and develop their language and culture, seemed to have provided new challenges for the Rom population (Engebrigtsen, 2010; Fuglevik, 2014; Persson, 2014). European political goals and efforts to include the Roma in national societies signified a resilient effort to educate the children and to employ the adults in wage labour. This again meant strengthened control and surveillance of family life and movements. An outcome of this internationally backed effort to educate the Rom children in mainstream schools was that absence from school was increasingly seen as child neglect (Persson, 2014). This interpretation of school absence among Rom children leads Child Protection Services to involve themselves in these families, to control the children's "circadian rhythm", the family's travel plans and emotional climate (Persson, 2014).

Contrasting the pluralistic theme of the 70 s and $80 \mathrm{~s}$, the minority politics we now see emerging is an expression of the new centennial's increasing preoccupation with individual rights and, with it, minorities duties to conform to a common norm. With this, and with the new European common measurements for school performance (Pisa), education became a crucial part of the nation's quest for economic progress and political significance in Europe and the world. Although the Framework Convention is founded on a liberalistic individual rights context, its objective is, nonetheless, to ascertain the rights of national minorities to keep and develop certain collective traits such as religion, language and cultural traditions. As such, it could represent a challenge to the strong emphasis on individual rights in educational politics.

Around 350 of the Rom population are children and around 73 of them are aged $6-13^{16}$. After 1992, Rom children were enrolled in ordinary classes in Norwegian schools under the pretext: "Gypsies shall, as far as possible, be treated as any other citizen" (Nordby, 2013).

Equal, including and accommodated education is an overarching principle in school. This implies that education must be accessible for all, and that all shall have good opportunities for learning, mastering and development. Pupils and apprentices are different, hence they have different needs and conditions. The same educational offer for all does not imply an equal offer. In order to supply equal education schools must provide varied and differentiated training. (St.meld.nr.30, 2003-2004:85 in Nordby, 2013, p. 12)

${ }^{16}$ (Handlingsplan for å bedre levekårene for rom i Oslo, 2009)
To support the schools in this effort, each Rom pupil "released" supportive funds to compensate for their lacking basic education. These funds were used to employ special assistants, to supply extra "teacher-time" and to buy different kinds of teaching aid. Two master theses from 2013 have analysed inclusion strategies in three Oslo schools with Rom-pupils (Bjørndal, 2014; Nordby, 2013). The finding was that teachers in these schools were aware of the special cultural and ethnic conditions of these children and used the extra funding to benefit the Rom children specifically. During, "less important subjects," two of the schools place the Rom children into groups with extra teachers to provide them with supplementary lessons in reading, writing and mathematics.

\section{Action Plan to Improve the Life-Situation for Roma in Oslo (Handlingsplan for å bedre levekårene for rom i Oslo, 2009)}

In 2009 the then Ministry of Work and Inclusion presented an Action Plan to improve the situation of Norwegian Roma in Oslo. This initiative was a response to the European Council's repeated call for more concrete plans to include the Roma into Norwegian Society. The Action Plan was developed together with Rom representatives and the Municipality. The Plan recommended ten measures, but did not suggest changes in the schooling situation for primary and lower secondary school. It did, however, recommend a new educational initiative for young adults without basic education. The idea was that educating young parents would make them more favourable towards education for their children. The Action Plan also recommended developing a tutoring system for Rom children in Norwegian classes, so called Rom-pilots, to act as mediators between school and home and to support teachers and children. These two measures were the only ones that concerned education and both were implemented the following years.

The action plan was evaluated in 2014 (Tyldum \& Horgen Friberg, 2014). The evaluation concluded that the Roma had not shown much interest in education, but that they generally attended school for social purposes and approached the teachers for all sorts of assistance in private matters. The teachers' tasks appeared to be rather contradictory; their task was to teach, to which the Roma showed little interest, whilst the Roma's genuine interest in asking for assistance in their dealings with authorities etc. was not part of teacher's duties. The report further concluded that the Rom tutoring system for Rom children in primary school was successful and should continue. It is not clear from the report why this measure was regarded a success, but it seems the schools had reached a closer understanding with parents through this measure. 


\section{Educational Ideals and Rom Resistance}

\subsection{Educational Ideology: The Hidden Curriculum}

Education is one of the state's central socialising institutions with the explicit objective of turning individual family subjects to collective beings that incorporate central values and practices of majority society and state. In Norway, a strong commitment towards equal education for all, grounded on individual conditions, encourages this general ideal for public education. Education of the Roma has, as discussed, gone through several ideational and political changes. For example, during the 1970 s to 80 s with what we today would characterise as a multicultural phase; where the emphasis was on preparing the Rom children for social and cultural integration through education based on their collective identities as Roma. Then in the 1990s, with a stronger emphasis on the development of knowledge-based education of each pupil with respect to their personal conditions. To today where we see an even more individualised education, where social and cultural conditions of the Roma are seen as more or less irrelevant and, sometimes, even problematic for education.

\subsection{The Hidden Curriculum}

These ideas represent the open curriculum of schools; they are expressed as objectives by governments which represent shifting educational ideas and policies. The disciplining and developing force of the hidden curriculum in basic education, a topic much discussed by scholars in the $20^{\text {th }}$ century from Dewy (1916) through Giroux (1983) and Bourdieu (1984), has, however, not been a topic in any of the evaluations and discussions of education for Rom children in Norway.

The disciplining force of institutions; (Bourdieu, 1986; Foucault, 1991; Meyer, 1986) by organising time and space, roles and relations, are perhaps the most important resources for a state in controlling and guiding a population, and for the individual's chances to convert these resources to social and economic capital. Adapting to the hidden curriculum in education provides the basic cultural capital to succeed in the Norwegian work force. By forging time structures in children that require them to sit quietly for a set period of time and see working with theoretical themes as natural and self-evident. By secluding children in predefined spaces for a predefined time span and by children accepting or submitting to the authority of a stranger outside their family, in this case that of Norwegian authority, a habitus ready, primarily for the Norwegian labour market, is developed. In Norwegian schools today, there is a basic agreement of the importance of education between home and government, although class, ethnicity, religion and other aspects of pupils backgrounds render the process of forging the proper habitus more or less smooth.

\section{Rom Habitus}

There are some basic traits that need to be taken into consideration to understand Rom habitus; the history of the Roma in Europe and the incorporated way of life and cosmology as it is lived and experienced among Roma in Norway. In the 1970s, John Ogbu developed the notion of "involuntary minorities" (Ogbu, 1974) to differentiate between minorities and school achievements in the US. His argument was that minorities that somehow have, "been brought to their present society through slavery, conquest or colonization" (Gibson, 1997, p. 319) seem to view public education as part of the oppression they feel they are subjected to (Gibson, 1997).

One trait is the deeply felt and ritually confirmed separation of the concept of Rom and that of Gazo, (non-Rom) based on historical experiences as a persecuted minority. The second, is the development of a mode of subsistence outside of state and wage labour, based on a history of economic marginality. The third, the deep-seated sense of belonging to family and kin, and the great sense of personal and collective autonomy and superiority as Roma (Engebrigtsen, 2007, 2013; Frazer, 1995; Lidén \& Engebrigtsen, 2010; Mirga, 1992; Stewart, 1997).

The spiritual separation between Roma and nonRoma that is paired with an economic dependency on the majority population implies that Roma are obsessed with keeping separate what can be kept separate; language, knowledge and morality. The Norwegian Roma, only numbering approximately 700 , express a feeling of having their backs against the wall and being in a precarious situation. Although they are few in Norway, they are, however, part of a European Rom population that is connected by kinship and marriage. To travel is not only crucial for holding up these networks, but also for confirming and "updating" one's identity and values as Roma in relation to the Roma of their networks. Travel is also important in order to evade unwanted projects and measures; it eases the pressure for a while. Additionally, to survive outside wage labour for people with sparse economic resources means having to utilise large areas, which makes mobility necessary. The strong commitment to family and kin all over Europe is based on and confirmed by physical presence and continuing exchange, and means that mobility in and out of Norway is a necessity for the Norwegian Roma to maintain their community (Hanisch, 1976; Hjemdal, 1982).

My interpretation is that many Rom populations have been more or less forced to rely on their own resources to survive as they have been, and still are, disqualified for ordinary wage labour. This subsistence 
strategy implies the necessity to exploit many resources over large territories and to do so in family groups where all hands are needed. They have to travel, they have to keep together and they have to teach their children necessary skills to develop the cultural capital required to manage that mode of subsistence. This strategy is the source of the Rom habitus that upholds the deeply felt separation between "us" the Rom and "them" the Gaze, a protective device towards continuous projects and programs of assimilation and integration throughout the centuries. A former teacher expresses the central position of travel to the Rom habitus: "It is by travelling they learn to be Gypsies". This is the domestic transition of cultural capital that is realised by spending time together.

In Bourdieu's sense, education provides the child with cultural and social capital that confirms the general social structure of the given society and prepares them for participation (Bourdieu, 2004). This allegation is confirmed by most research on education and social class that finds that, at least in western societies including Norway, class structures are confirmed through education (Bourdieu \& Passeron, 1990; Giroux, 1983; Levinson, Foley, \& Holland, 1996). Children from the upper levels of society with parents who have completed higher education do better in school than children of less educated parents (Bakken \& Elstad, 2015), and have better bargaining power in the quest for economic capital. Although this fact is a concern for most governments, school education is a relatively doxic field for politicians and planners in Norway. Education is seen as, "a common good", liberating and enabling for all, irrespective of the different outcomes related to the different class- and ethnic belonging of children.

\section{Cultural Capital and Public Education: The Roma's Response Analysed}

Throughout all educational projects presented to the Roma, the response from the Rom population has been double-sided. They have consented orally to the majority argument about their children's need of education while, in practice, most children have either not attended school, or have done so irregularly. I argue that this "double" response is an expression of the rather precarious situation of the Norwegian Roma. Being economically dependent on welfare and "black" business in different combinations and forming a separate community in Norway renders the Roma vulnerable to control and assimilation. This situation makes it necessary to express willingness and gratitude towards the authorities' efforts to include them. By doing so they are tolerated and are able to keep and develop their own cultural values and ways of life. ${ }^{17}$. They appeal to

17 This is my interpretation based on my work with Roma and my experience with their response to authority projects. the tolerance and benevolence towards vulnerable groups and, "exploit the cracks in the enemies armour" to put it poetically (de Certeau, 1984, p. 37)

Bourdieu views formal education as the elementary provider of social and symbolic capital in western society (1986). Bourdieu's theory of symbolic capital is well suited to analyse Rom resistance. That knowledge, for instance, in the form of educational qualifications and social networks, is accumulated work and thus function in a chain of exchange with economic capital. Thus, in any order, achieved knowledge can lead to important acquaintances which can then be converted into economic capital. This capital conversion is tied to specific fields with specific social structures and value systems (Bourdieu, 1983). The Rom social world and subsistence economy rest on knowledge gained by participating in the economic activities of the Roma in Norway and elsewhere. Thus, time invested in school means less or no time invested in the Rom world. The crafts, skills and Rom habitus necessary to cope with that way of life will, at worst, be de-valued or left undeveloped in children. The social and cultural world of school is completely adversary to Rom family life, with its specific organisation of time-space (Nordby, 2013). As one mother expresses: "The children live with us in our adult life. As we do not have a job, we are up sometimes to two PM. and the children are with us. No mother will wake her child up at seven when there is $10^{\circ} \mathrm{C}$ outside. Cause the mother has not been to school and has not become someone. It's a vicious circle" (Nordby, 2013, p. 51). Rom children are not disciplined according to abstract principles and schedules, but according to the adults' practices, feelings and preoccupations. Confinement to a controlled space under the authority of an adult that is neither family nor Rom, will generally trigger fierce resistance.

Respect is a central value and resource among Roma, and in order to achieve respect one must adhere to the Rom value-system and socialise with respectful Roma. This again means having the knowledge of how to behave respectfully. This knowledge can be converted to social capital: networks of influential Roma that can again be converted to business opportunities or profitable marriages (of children or other relatives).

According to Rom traditions, youth are ready for marriage from the ages of 14-15 and signifies their transition into adulthood. At that age, a child should have incorporated the necessary knowledge to lead an adult life with spouse, children and responsibilities, supported by close family. In order to complete an education, this practice must be broken. According to the Roma, a school education is not a resource convertible to social or economic capital in their community, but rather a threat to their way of life. I do not see the Roma's self-segregation (Mirga, 1992) as a question of choice and strategy, but as an expression of the Rom habitus and the strategic situation of the Roma in in re- 
lation to non-Roma. It could also be seen as a response to the still existing negative prejudice and discriminatory practices they experience.

\section{Closing Remarks}

Two young Roma have completed high school and vocational training since the Norwegian Roma settled permanently after the Second World War. What made that possible? The question itself is complex. As their mothers were both married to non-Roma they held an ambiguous positions in the Rom community. For the boy that meant he did not have a father that knew and could teach him Rom trades. The girl did have a Rom father, but her mother divorced him and remarried a man who supported her daughter's school attendance. When the boy's mother died, he married a Rom woman, stopped practicing his craft and began business with his Rom relatives. Furthermore, shortly after completing high school, the young girl ran away with a Rom from another group and started a family abroad. These examples and the general experience of Rom parents that their children learn "nothing" in school, confirms their reluctance to send them.

Since being established, the programs for integration and inclusion of the Rom population have emphasised two basic intentions and goals: 1) The Rom population is expected to keep and develop their culture and 2) The Roma shall be included/integrated into Norwegian society in terms of education, wage labour and a settled lifestyle (St.meld.nr. 37 (1972-73) Om tiltak for de norske sigøynere, 1973; Handlingsplan for å bedre levekårene for rom i Oslo, 2009). Based on my argument of Rom culture as habitus, the nature of this contradiction becomes rather obvious. In order to respond to the intentions of the integration/inclusion programs, the Norwegian Rom population will have to change their way of life, their collective and personal identity and culture. I am not implying that Rom habitus and culture is unchangeable, only that change that attack their core institutions triggers gut reactions; more or less intended resistance.

As has been demonstrated throughout this article, Norwegian authorities have not used force in educating the Roma. They have tried, in different ways, to acclimate education to the Rom way of life. They have tried to support education whilst the families were travelling, they have experimented with mother-tongue education and they have tried to treat Rom children "just as all other children". The results have been much the same; whatever educational model the Roma have been subjected to, they have done what they generally do; consent orally and resist in practice. As long as the Norwegian Roma see their own way of life, social organisation and value systems as preferable to that of the non-Rom, formal education will not become a resource that can be converted as it will not become capital.

\section{Conflict of Interests}

The author declares no conflict of interests.

\section{References}

Achim, V. (2004). The Roma in Romanian history. Budapest/New York: Central European University Press.

Bakken A., \& Elstad J. I. (2015). The effects of parental invome on Norwegian adolescent's school grades: A sibling analysis. Acta Sociologica, 58, 265-282.

Bergesen, H. O. (2006). Kampen om kunnskapsskolen. Oslo: Universitetsforlaget.

Bjørndal, K. (2014). "Det er på tur de lærer å være sigøyner". Perspektiver på utdanning for rombarn 1999 til $i$ dag. Unpublished master disseratation, Faculty for Teacher Education and International Studies, Oslo University College, Oslo.

Bourdieu, P. (1983). The forms of capital. Goettingen: Otto Schartz\&Co.

Bourdieu, P. (1986). Outline of a theory of practice. In J. Goody (Ed.), Cambridge studies in social anthropology. Cambridge,London, New York: Cambridge University Press.

Bourdieu, P., \& Passeron, J.-C. (1990). Reproduction in education, society and culture. Sage publications Ltd.

Bourdieu, P. (1984). Distinction: A social critique of the judgement of taste. London: Routledge and Kegan Paul.

de Certeau, M. (1984). The practice of everyday life. Berkely, CA: University of Californya Press.

Dewy, J. (1916). Democracy and education. New York: Dover Publications.

Engebrigtsen, A. I. (2007). Exploring gypsiness. Power, exchabge and interdependence in a transylvanian village. New York, Oxford: Berghahn Books.

Engebrigtsen, A. I. (2013). Great ideas, bad practices: On implemetation of policies and programmes for Roma. In M. Goodwin \& P. De Hert (Eds.), European Roma intergation efforts: A snapshot. Brussels: Academic\&Scientific Publishers.

Engebrigtsen, A. I., \& Lidén, H. (2010). Å finne sin plass som minoritet: Rombefolkningen i Norge i dag. In A. Bonnevie Lund \& B. Bolme Moen (Eds), Nasjonale minoriteter i det flerkulturelle Norge. Oslo: Tapir Forlag.

Engen, T. O. (2010). Enhetsskolen og minoritetene. In A. Bonnevie Lund \& B. Bolme Moen (Eds), Nasjonale minoriteter i det flerkulturelle Norge. Oslo: Tapir Forlag.

Foucault, M. (1991). Governmentality. In G. M Burchell, C. Gordon, \& P. Miller (Eds.), The Foucault Effect. Hemmel Hemstead: University of Chicago Press.

Framework Convention on the Protection of National Minorities. (1995). Strasbourg, 1.II.

Frazer, A. (1995). The Gypsies. London and New York: Blackwell Publishers.

From, C. (1985). Norske sigøyneres forhold til skolen. Unpublished master thesis, Institutt for sosialant- 
ropologi, University of Oslo, Oslo.

Fuglevik, A. (2014). Norske myndigheters skoletilbud til norske rombarn (1973-1992). Unpublished master thesis, Flerkulturell og internasjonal utdanning, University College of Oslo and Akershus, Oslo.

Gjerde, L. (1996). Rom I Norge og deres barn's skolegang. I Rom-prosjektet: Tilpasset undervisning for sigøynerbarni samarbeid med deres foreldre. Oslo: Nedre Bekkelaget skole.

Gibson, M.A. (1997). Introduction. Exploring and explaining the variability: Cross-national perspectives on the school performance of minority students. Anthropology \& Education Quarterly, 28(3), 318-329.

Giroux, H. (1983) Theories of reproduction an resistance in the new sociology of education: A critical analysis. Harvard Educational Review, 53(3), 257-293.

Handlingsplan for å bedre levekårene for rom i Oslo. (2009). Oslo: Ministry of Work and Inclusion.

Hanisch, T. (1976). Om sigøynerspørsmålet: en undersøkelse for bakgrunnen for sosial konfrontasjon. Olso: Institutt for Samfunnsforskning, Universitetet i Oslo.

Hjemdal, O. K. (1982). Evaluering av arbeidet med sigøynerne [Evaluation of the actions for the Gypsies]. Oslo: Sosialdepartementet.

Levinson, B. A., Foley, D. E., \& Holland, D. C. (Eds.) (1996). The cultural production of the educated person. Critical ethnographies of schooling and local practice. New York: State University of New York Press.

Lidén, H., \& Engebrigtsen, A. I. (2010). De norske rom og deres historie. In A. Bonnevie Lund \& B. Bolme Moen (Eds), Nasjonale minoriteter i det flerkulturelle Norge. Oslo: Tapir Forlag.

Lidén, H. (1990). Vokse opp som sigøyner i Norge; sosilaisering i en etnisk minoritetsgruppe. Magister thesis, Department of Social Anthropology, University of Oslo.

Maton. K. (2008). Habitus. In Pierre Bourdieu. Key concepts. Durham: Acumen.

Meyer, J. W. (1986). The self and the life-course: Institutionalization and its effects. In A. B. Sørensen (Ed.), Human development and the life course: Multidisciplinary perspectives,. Hilldale, NJ: Lawrence and Erkbaum Ass.
Mirga, A. (1992). Roma territorial behaviour and state policy: The case of the socialist countries of East Europe. In M. J. Casimir \& A. Rao (Eds.), Mobility and territoriality. Social and spatial boundaries among foragers, fishers, pastoralists and peripatetics. New York and Oxford: Berg.

Nordby, M-J. ( 2013). Inkludering av romelever i skolen. En kvalitativ undersøkesle om inkludering av romelever i skolen med fokus på kulturforståelse og systemperspektiv. Unpublished master thesis, Faculty of Pedagogic University of Oslo, Oslo.

Ogbu, J. O. (1974). The next generation: An ethnography of education in an urban neighborhood. New York: Academic Press.

Persson, M. J. (2014). Rom for forskjell? Barnevernsarbeideres forståelser, vurderinger og handlinger $i$ arbeid med norske romer. Unpublished master thesis, Faculty of social science, University College of Oslo and Akershus, Oslo.

Rosvoll, M. (2015). "Å bli den kvit»: Utviklingen av en "sigøynerpolitikk» og utryddelsen av norske rom. Oslo: Holocaustsenteret.

Skarpenes, O. (2007). Kunnskapens legitimering. Fag og læreplaner i videregående skole. Oslo: Abstrakt forlag.

St. meld. Nr. 30 (203/204) Kultur for læring [White Paper on education]. Oslo: Forskningsdepratementet.

St.meld.nr. 37 (1972-73) Om tiltak for de norske sigøynere [White Paper on measures for the Norwegian Gypsies]. (1973). Edited by Sosialdeprtemenetet. Oslo: Sosialdeprtementet.

Stewart, M. (1997). The time of the Gypsies. Colorado: Westview Press.

Takle, M. (2010). National reproduction: Norway's new national library. Nations and Nationalism, 16(4), 753773.

Tyldum, G., \& Horgen Friberg, J. (2014). Et skritt på veien. Evaluering av handlingsplan for å bedre levekårene for rom i Oslo. Oslo: Fafo.

Vermeersch, P. (2012). Reframing the Roma: EU Initiatives and the Politics of Reinterpretation. Journal of Ethnic and Migration Studies, 38(8).

Wells, K. (2015). Childhood in a global perspective. Cambridge: Polity Press.

\section{About the Author}

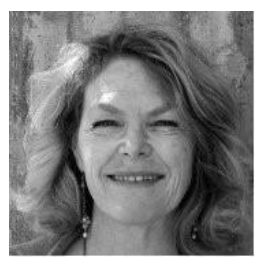

\section{Dr. Ada I. Engebrigtsen}

Ada I. Engebrigtsen is an anthropologist and research professor at the Norwegian Social Research NOVA-Centre for Welfare and Labour Research (SVA) at the University College of Oslo and Akershus. Her main research areas are migration (focused on adaptation processes), interethnic relations, and childhood studies. Romanian and Norwegian Roma, and Somali refugees in Norway have been central to her research. 